\title{
Application of Local Wisdom in Ethical Leadership for Catholic Education Institution (A Hermeneutic Analysis on Manggaraian Local Wisdom in Education)
}

\author{
Yohannes Don Bosco Doho ${ }^{1}$, Suryadi ${ }^{2}$, Neti Karnati ${ }^{3}$ \\ \{yohanes.dbd@1spr.edu ${ }^{1}$, hcsuryadi@gmail.com² ${ }^{2}$ netikarnati@unj.ac.id ${ }^{3}$ \} \\ Universitas Negeri Jakarta, Indonesia ${ }^{1,2,3}$
}

\begin{abstract}
Wisdom is an indigenous value that belongs to a local place, village or region and which is related to its ethical values. In the philosophical context, wisdom is inherent in every human being and also reflects in leadership abilities. Leaders are needed in every institution, education inclusive, and their position requires that they keep ethical values and apply wisdom in discharging their duties. Therefore, the aim of this article was to analyze the application of local wisdom in ethical leadership in Catholic Schools of Manggarai Flores. The research was conducted qualitatively through the application of phenomenology while the information gathered was analyzed by using hermeneutics model of Hans Georg Gadamer. Three experienced and long-serving principals of Catholic schools were interviewed and it was discovered that they all applied principles of ethical leadership in their schools. The result also showed that the key success of these principals was found in the application of Manggaraian local wisdom in their leadership style in conducting the affairs of the Catholic schools.
\end{abstract}

Keywords: Ethical leadership, local wisdom, hermeneutic, education institution.

\section{Introduction}

Ethics and local wisdom are two interconnected concepts. Each region has its own uniqueness and wisdom and these usually guide and binds their citizens' actions. Greek philosophers, Plato and Aristotle, viewed wisdom as a basic human virtue and also as the highest form of knowledge. It is not merely an intellectual pattern but a concept that is directed towards values and emotions. Finally, it is an ability to give decisions correctly and precisely on matters relating to life and behavior; the accuracy of a decision in having practical means and goals for everyday life. Local wisdom animates almost all aspects of human life, including leadership in any organization. Therefore, this article explores the application of local wisdom in ethical leadership with focus placed on Catholic educational institutions in Flores area, Indonesia. However, the local wisdom that was applied in educational leadership of this region is in line with the pillars that were sparked by Ki Hajar Dewantara namely Tut wuri handayani, ing ngarso sung tulodho and ing madyo mangun karso. At the same time, the leadership applied in the local wisdom of the area was 
compared to the educational goals proclaimed by UNESCO which are learning to do, to know, to be, and to live together. The analysis was done and interpreted using the hermeneutic framework developed by Hanz Georg Gadamer.

\subsection{Study Question}

With respect to the information provided above, the research question was formulated to be: How can a Catholic education institution leader apply ethical leadership based on local wisdom?

\section{Literature Review}

\subsection{Leadership Concept}

Leadership has always been the focus of many researchers because of its importance. The essence of leadership, including ethical leadership, is to influence others to work together in order to achieve the desired goals[1]. It is important to point out that for leaders to be able to influence the people they lead, there must be some level of interaction. This is used to adjust followers to the context and situation in which a leader plays his role. Although this influence may be carried out in various styles, the basic philosophy of leading is the spirit of service. Serving wholeheartedly with no strings attached is the dream of all who are led. Therefore, this should be considered when making reference to the styles and models of leadership put forward by experts such as charismatic, transformational, visionary and ethical leadership.

\subsection{Ethical Leadership}

Firstly, ethical leadership focuses on a moral person with ethical charisma such as honesty, trustworthiness, and altruism. Secondly, it has to do with moral managers that used their ethical behavior such as fairness, caring, communicating, rewarding, punishing, ethical standards emphasizing, and role modeling ethical behavior to shape the behavior and attitude of their followers[2]. Meanwhile, Schermerhorn stressed that "ethical leadership is characterized by caring, honest, principled, fair and balanced choices by individuals who act ethically, set clear ethical standards, communicate about ethics with followers and reward as well as punish others based on ethical or unethical conduct"[3]

\subsection{Local Wisdom}

The term local wisdom became popular in the last 10 years. It was initially a subject of discourse in the 1980s when the values of the local culture of Indonesian people were almost eroded by the flow of modernization that shaped how things are done under the New Order regime. The term was used to refer to a unique knowledge (praxis or theoretical) or certain ways of life that are owned by certain groups of people. In other words, local wisdom is a part of cultural construction that involves the growth and development of various cultural properties that are 
known, trusted, and recognized as important elements capable of strengthening the power of social adherence among citizens in a society.

Local wisdom[2] has six significant functions: it is a marker of identity for a community; an adhesive element between citizens across religions and beliefs; not compelling, but lives within the society; holds members of a community together; changes the mindset and reciprocal relationships of individuals and groups on the basis of common ground; and encourages the development of togetherness needed for communal solidarity. An example of this can be seen in the consideration of batik cloth and a calendar system regarding agricultural activities and trade in traditional markets in Java as Javanese local wisdom.

From a philosophical perspective, local wisdom contains regional values that inspire the growth of humanism and the uniqueness of cultures that exist in certain environments. In every local wisdom, there is a wealth of moral messages and values of optimism that grow and develop until they are recognized as the universal truth.

The term "wisdom" means more than mere wisdom in the general sense, but also an intellectual effort. The word 'Sophia' is described in the philosophical terms to be the knowledge of reality and it was mostly sought by philosophers at the time. This can be attributed to its ability to improve the standard of living. However, this term is now mostly used in everyday common language to be related to moral teachings or ethics and not in the sense of moral philosophy. The important question to ask is whether local wisdom is understood as a mere knowledge of ethics or as a broader and unlimited knowledge of ethics. Nevertheless, since the word "local" appears as a prefix for the concept, it must be localized.

From the first instance, local wisdom is understood as a noble knowledge or outlook on life in a local community. Wisdom has been originally described to mean moral virtue and not as an ethical issue in the sense of a value system. This means that it can be referred to as a noble view of life from a local perspective[4].

In the second instance, the term can be interpreted as a local knowledge or the knowledge held by a local community about everything. This can be attributed to the presentation of "wisdom" as "knowledge" in various philosophical discipline of Greece. The type of knowledge presented in this case is broad and, therefore, not limited to ethical issues. The knowledge intended in the above definition includes the static and dynamic type. Static or permanent type refers to the knowledge that is related to tradition. This notion of local wisdom actually refers to life views inherited from previous generations or ancestors of local communities whose truth is considered permanent. Therefore, in this case, all life issues are always resolved through the knowledge inherited by tradition.

Local wisdom is seen in many cultural studies conducted by academics on society in developing and poor countries. It is mostly referred to as "local genius" and observed as an explicit knowledge that emerges over a long period of time. The evolution of this knowledge happens with respect to the experiences of the people in the community and their environment. The inherent long process involved in the evolution ensures that local wisdom becomes a reference source of a shared life. This notion makes it possible to input dynamic knowledge in a civilized society. In this context, local wisdom can help in controlling exposure to global values. This means that the society may not become outdated by respecting cultural products that come as a result of the revitalization of its knowledge and understanding its customs so as not to lose its direction and identity. 
From the foreign perspective, the term is mostly referred to as "local knowledge", "local intelligence", and "local genius". They are believed to be truthful values that set the standard for individuals in a particular local community behaves on a daily basis. Clifford Geertz claims that local wisdom is an entity that greatly determines human dignity in a community. Furthermore, Sternberg argues that local wisdom is a manifestation of various values and perspectives that are just not about people knowing (knowing that). It can also have a framework of reasoning about how to know (knowing how) as a form of Tacit Knowledge (TK) in order to be able to apply critical thinking methods.

\section{Material and Methods}

This study made use of interpretive paradigm qualitative research method. Data was collected through in-depth interviews, focus group discussions and observation. The data collected were analyzed using the hermeneutic circle as designed by Hanz Georg Gadamer. (See at: https://osf.io/n96bu/ )

\section{Discussion}

Manggaraian people possess strong local wisdom such as traditional wisdom in leadership in their daily life. It was discovered that leaders of Catholic institutions always help the community by leading teachers, education staff and students. Ethical leadership has been discovered to be prominent in society by following the tradition of toing, teing, titong, tatong, takung, toming, and tinu. The respondents pointed out that for toing, a leader should teach all good things in form of knowledge, information, and values. They also revealed that teing involves giving something important such as knowledge, materials, and impression to all, especially the students. Titong was stated to include guiding people to do good and avoid engaging in the wrong and prohibited things. The students were taught to pursue good manners. Tatong has to do with keeping and saving people from everything that may hinder their future. Takung involves filling people with new hope needed to lead a fulfilled life. Toming includes teaching, leading and managing by a good example. Lastly, tinu has to do with maintaining and keeping everything that has been learned from the leader, teacher or parents.

From the analysis conducted according to hermeneutic circle and based on understanding, interpretation, and application, four factors were observed for interpretation and they are as follows:

1) Bildung: This illustrates how humans develop their talents. It is an established way of thinking that is related to the process of understanding and interpretation. It shows that experience plays a role in understanding and interpreting texts. Thus, the interpretation of two people with different backgrounds, cultures, ages and education levels will not be the same. This article reveals that context cannot be separated from interpretation and for Manggarai people to recognize the meaning of local wisdom, they must experience it. 
2) Sensus communis: This involves good practical consideration and helps in handling interpretations. This term refers to the social aspects of interaction within the community. Ancient philosophers called it "wisdom" or "conscience" and historians really need it to understand the background that underlies the pattern of human attitudes.

3) Considerations: Classifying things that are specifically based on views about the universe or recognizing something as an example of the realization of law. In this case, consideration is mainly understood as something that is related to what must be done, something that cannot be learned or taught but can only be implemented from one case to another.

4) Taste: A balance between the five senses and intellectual freedom. Tastes can make humans retreat from the things they like, and convince them to make necessary judgments.

The value of local wisdom crystallized in the tradition of toing, teing, titong, tatong, takung, toming and tinu has become the basis for ethical leadership at the Catholic educational institution in Manggarai Flores. Kisol Seminary Pius XII Senior High School principal applied exemplary values, willingness, and sincerity in providing assistance according to the five hallmark values of the school. These include integrating the dimensions of holiness (sanctitas), science and intelligence, sanity, wisdom (Sapientia), and solidarity in accordance with the stages of development in answering God's call. SMAK St. Klaus principal leads by holding on to the best inheritance of character which is the basic value of Catholic cadre pioneered by its founders. The people that fall under character cadre holds local cultural values in high esteem despite their exposure to the modernization of the civilized world. SMAK St. Ignatius Loyola principal engaged in leadership that focuses on the use of education to help young people uphold the values of local wisdom.

It can be discovered that all the three principals made use of ethical leadership in leading their respective educational institutions. Their graduates are capable of doing good things with integrity, live in harmony with others at work, service and in life. These feats are only achievable through the ethical values instilled in them by their respective leaders and it reinforced the submission that exemplary leadership enables followers to maintain good traditions, character, and knowledge. The leaders of the three Catholic education institutions analyzed in this study understand local wisdom of Manggarai and they used it as a guideline in planning, directing, and controlling their followers in accordance with the cultural values that are typical of the community.

\section{Conclusion}

From the hermeneutic analysis carried out, it can be concluded that ethical leadership values built on the local wisdom of Manggarai Flores have been expressed in the three Catholic educational institutions studied. They were able to use ethical leadership to instill honesty, integrity, trustworthiness and other qualities of good human beings in their students and it also helped the students to live good lives. Local wisdom has been identified to be a major force in retaining societal identity, moral and cultural values. 


\section{Suggestions / Recommendations}

1. The world has been disrupted by civilizations to the extent that values of local wisdom, including the ones related to education and leadership, has been eroded away. All stakeholders in human and youth development must ensure that they engage in practices of local wisdom because of its richness in moral and ethical messages.

2. The three educational institutions used in this research should strengthen each other so that the values of local wisdom will be held firmly in the midst of the uncontrollable strong current of globalization and information. This is necessary because strengthening ethical values during the education process will raise students to become people that are ready to learn, live together, become real human beings and know everything that is beneficial for their lives.

3. Ethics form the basis and guideline for good behaviors and happy living. Since every local wisdom absolutely contains high ethics, they should be strengthened in leadership and education.

\section{References}

[1] E. a. Katarina Katja Mihelič, "Ethical Leadership," Int. J. Manag. Inf. Syst. - Fourth Quart., vol. 14, (2010)

[2] Maya Sopa, "Local Wisdom in the Cultural Symbol of Indonesian Traditional House" in The 1st Annual International Conference on Language and Literature," 1st Annu. Int. Conf. Lang. Lit. KnE Soc. Sci., hal. 524-531, (2018)

[3] J. G. H. and R. N. O. John R. Schermerhorn, Organizational Behavior, 11 ed. New York: John Willey \& Sons, Inc, 2011.

[4] "https://www.researchgate.net/publication/318880238_Local_Wisdom_and_Communal_Function_in_ The_Oral_Literature_of_Kafoa.”.

[5] Abdullah, Irawan, $\overline{d k k}$. 2008, Agama dan Kearifan Lokal dalam Tantangan Global, (Yogyakarta: Sekolah Pascasarjana UGM), h. 86

[6] Andrew J. DuBrin, Principles of Leadership, $7^{\text {th }}$ Edition (South-Western: Cengage Learning, 2013), h. 144

[7] Ayatrohaedi, Kepribadian Budaya Bangsa Lokal (Local Genius), (Jakarta: Pustaka Jaya, 1986), h. 1819.

[8] Cammi L. Derr, Ethics and Leadership, Journal of Leadership, Accountability and Ethics, Vol. 9 No. 6, 2012, h. 67

[9]Gary Yukl, "An Evaluative Essay on Current Conceptions of Effective Leadership”, European Journal of Work and Organizational Psychology, 1999, 8 (1), h. 30

[10] Gary Yukl, Kepemimpinan Dalam Organisasi, edisi kelima, (Jakarta: Indeks, 2009), hh. 480-481.

[11] Husserl dalam Kockelmans, Phenomenology, Doubleday Anchor, 1967, h. 10

[12] Joanne B.Ciulla "The state of leadership ethics and the work that lies before us", Business Ethics: A European Review, Journal Compilation 2005 Blackwell Publishing Ltd, 9600 Garsington Road, Oxford, OX4 2DQ, UK and 350 Main St, Malden, MA 02148, USA, hh.324-325

[13] Shukurat Moronke Bello, "Impact of Ethical Leadership on Employee Job Performance", International Journal of Business and Social Science Vol. 3 No. 11; June 2012, h. 229

[14] Michael E. Brown \& Linda K. Treviño Ethical leadership: A review and future directions”, The Leadership Quarterly 17 (2006), available on www.sciencedirect.com, hh. 595-616 